\title{
Deterministic For Rain Water Harvesting Storage Capabilities with the Design Curve Technique, A Strategy for Attaining Copiousness of Water
}

\author{
James NTAYOMBA, Li Xiao Ying, Etienne GASASIRA,BWIMBA MUGANGA Godfrey, \\ Alexandre TWIRINGIYIMANA
}

\begin{abstract}
Considering fecal contaminations of drinking water sources resulted from the storm runoff in the view of global access to safe drinking water, Fecal contamination varies with time while its monitoring is often rare.It is from this acumen,Rainwater harvesting systems (RWH) has become a prevalent water saving and conservation means across the world. In many cities, a pre-determined rainwater tank size is mostly selected without a detail water balance modelling at the location. Nevertheless, to attain a maximum use from a RWH system at a given location, it is required to design the scheme based on the site-specific environments (e.g., local rainfall and loss characteristics) and further pertinent design constraints. There have been limited studies on regionalization of RWH system, which can account for the spatial variability in rainfall, loss and water demand characteristics over a given region to provide site-specific design of RWH system storage capacities. This paper presents RWH approach to advance a set of design curves, which supports in the assortment of an adequate RWH system at a given location. Rwandan rainfall data from its agency Meteorological Agency across the western and northern regions are used to develop and test the proposed approach. It has been found that there is a significant variation in rainfall characteristics across the regions and that a common tank size across these regions does not present a satisfactoryresult. It has been found that a 5-kL tank can achieve a consistency (i.e., percentage of days the RWH can encounter the given demand) of $31 \%-93 \%$ for four people reliant on the location in the region and the types of water used. The developed regional design curves could result in an increased water savings; Theanticipated approach can be adapted to other cities across Rwanda and the world which contemporaryhas a high rainfall slope.
\end{abstract}

Index Terms - Design curves, rainwater tank, water savings, Reliability, Quality of harvested rainwater.

\section{INTRODUCTION}

Global access to safe drinking water is tracked by the Joint Monitoring Program for Water Supply and Sanitation (JMP) of the WHO and UNICEF as the proportion of the population using an improved drinking water source.It is notably that

James NTAYOMBA, College of Water resources and Hydropower, Hohai University, Nanjing, 210098, China.

Li Xiao Ying, College of Water resources and Hydropower, Hohai University, Nanjing, 210098, China.

Etienne GASASIRA, School of Electrical and Electronics, Rwanda Polytechnic (RP), Kigali, 6579, Rwanda.

BWIMBA MUGANGA Godfrey, College of Water resources and Hydropower, Hohai University, Nanjing, 210098, China.

Alexandre TWIRINGIYIMANA, School of Electrical and Electronics, Rwanda Polytechnic (RP), Kigali, 6579, Rwanda.
Water demand across most of the cities around the globe is on rise due to urban expansion and climate variability and changes wherean improved source is one that, by nature of its construction, adequately protects the source from outside contamination, particularly fecal matterTable.1[1].This indicator is a proxy for safety and does not account for actual contamination; This is a notable shortcoming as safe drinking water is defined by the WHO as water which does not represent any significant risk to health over a lifetime of consumption[2], and fecal contamination is considered to be the main threat to public health[3].A systematic review found that $38 \%$ of water quality studies of improved sources in low-income regions report at least a $\frac{1}{4}$ of water samples contain fecal contamination[4].When accounting for fecal contamination, estimates suggest that more than 1.8 billion people consume drinking water from a contaminated source[5-7].As such, monitoring of fecal contamination is considered by the JMP to be one of the next steps in improving global monitoring of access to safe drinking water[3].Fecal contamination of drinking water is monitored using fecal indicator bacteria (FIB)[2].Escherichia coli (E. coli) is currently recognized by the WHO and the JMP as the best FIB for monitoring fecal contamination of drinking water and thermotolerant coliforms (TTC) are suggested as an acceptable alternative[2, 3]. The WHO guideline value for E. coli in drinking water is none detectable in any $100-\mathrm{ml}$ sample[2]. In the United States, the Safe Drinking Water Act requires drinking water systems to be analyzed for total coliforms between once a month for the smallest systems and 480 times per month for the largest. All positive samples must then be tested for the presence of E. coli or TTC [8]. Due to limited resources, especially affecting developing countries, this level of sampling is not always achievable. Instead, FIB monitoring is often conducted using one-off or infrequent sampling, with up to a few sampleseach year[3].Unrepresentative sampling timing could impair the accuracy of fecal contamination estimates in these areas, as it is possible for FIB to be present only during occasional contamination events since microbial contamination varies with time and FIB generally do not survive longer than 28 to 84 days[9].Of particular concern is sampling during only one season. Season can refer to either astronomical divisions of the year (winter, spring, summer, autumn) or to divisions based on climatic periods (e.g., wet season(s), dry season). Seasonal variation of fecal contamination is an issue because 
although water quality is thought to usually be worse during the wet season [3],drinking water surveys, like household surveys Wright et al.[10], are often conducted in the dry season for logistical reasons such as accessibility of areas with unpaved roads. An understanding of seasonal trends in fecal contamination could help shape guidelines for sampling plans to decrease the chance of inaccurate and misleading fecal contamination data and enhance interpretation of available data. A known effect size in any trends (i.e., by how much does the contamination vary) could be used to assess the representative nature of past data if the sampling periods of those data are also known. While studies have shown that water quality parameters in surface waters Ouyang et al.[11], as well as some unimproved drinking water sources in

Table 1 Classification of drinking water source types according to JMP Improved drinking water sources developing countries,Wright.[12]follow seasonal patterns, it is from that fact Rainwater harvesting (RWH) system is considered to be one of the popular water supply management initiatives under sustainable urban water management to save potable water. Implementation of RWH is being promoted in many cities to address the increasing water demand[13-15].RWH can offer multiple benefits including expansion of mains supply for potable (e.g. drinking and cooking) and non-potable uses (e.g. toilet flushing, laundry and gardening), drought contingency dealings and urban flood management by detaining the peak flow[16-22].

Piped water into dwelling, yard or plot

- Public tap or standpipe

- Tube well or borehole

- Protected dug well

- Protected spring

- Rainwater collection

Unimproved drinking

water sources
- Unprotected dug well

- Unprotected spring

- Cart with small tank or drum

- Tanker truck

- Surface water (river, dam, lake pond, stream, canal, irrigation channel)

- Bottled water*(Bottled water* is considered as unimproved if the household does not use drinking-water from an improved source for cooking and personal hygiene).

tend to have a longer dry period during the austral winter with comparatively little rain from June to August while having a shorter and/or less dry period during the austral summer (December-February)[23].For Rwanda specifically, one study of historical station rain gauge data (up to the early 1990s) found that a little over $40 \%$ of the annual rainfall occurred in the March-May season between 30 and $40 \%$ occurred in the September-December season, and about 15-20\% occurred in January and February with June-August typically having only about $5 \%$ of the annual rain Muhire et al.[25].Another study found that the pluviometric coefficient (ratio of monthly rainfall to annual rainfall) is more spatially heterogeneous across the country in February and October than in other months potentially suggesting a role of additional sources of moisture (e.g., advection from the Congo and/or Atlantic). At other times of year the pluviometriccoefficient is morehomogenous. There has been regional hydro-climatic variability on multi-decadal timescales[25-28].On shorter inter-annual timescales, the El Nino-Southern Oscillation (ENSO) and the Indian Ocean Dipole (IOD) play a significant role in the rainfall patterns of Rwanda in particular and East Africa more generally[25, 26, 29-31].

\section{CURREnT STUdies}

Australian Bureau of Statistics [32]reported that around 38 dry period during the boreal summer (June-August). Locations a little south of the equator (including Rwanda) 
GL of water was saved in 2013 across the New South Wales (NSW) state in Australia by RWH system. Coombes[22, 33]found that the installation and use of $5 \mathrm{~kL}$ rainwater tanks has the potential to defer augmentation of water headworks in the Greater Sydney region beyond 2054. The Building Sustainability Index (BASIX) requirements in NSW cover water and energy usage and thermal comfort performance to all new residential dwellings and additions costing AU\$ 50,000 or more[34].According to BASIX, a RWH system must be installed in all the new dwellings to save at least $40 \%$ water. To assess water savings in Sydney by a RWH system, Rahman et al. [35] showed that a 5 kL RWH system could save between 54 and $69.5 \mathrm{~kL}$ of water per annum at a reliability ranging from 38 to $69 \%$ when rainwater is used for toilet, laundry and irrigation in a detached house. Furthermore, Hajani and Rahman[36]showed that a $1 \mathrm{~kL}$ RWH system providing water to toilet and laundry with a roof catchment area of $200 \mathrm{~m}^{2}$ had a reliability of $73 \%$ in Sydney which increased to $98 \%$ reliability and a potable water savings of $33 \mathrm{~kL}$ per annum for a 5kL tank. Ghisi[37]found that around $48-100 \%$ potable water demand could be met through implementing a RWH system depending on geographic location in Brazil. Around 0.27\%-19.7\% potable water savings in residential sector in Jordan by using RWH system was reported by Abdulla and AlShareef [38].In Germany,Hermann and Schmida [39]estimated the potential reduction in water demand by $30-60 \%$ when using 4-6 $\mathrm{m}^{3}$ tank for toilet flushing. The results obtained by Rahman et al. [35]in Sydney supports the findings of Coombes and Kuczera [40], who conducted an annual water savings performance analysis in Western Sydney region considering RWH systems providing water to toilet, laundry, hot water and outdoor uses. They calculated that rainwater tanks of $1 \mathrm{~kL}-10 \mathrm{~kL}$ for a range of 1-5occupants connected to roofs with areas of $100 \mathrm{~m}^{2}, 150$ $\mathrm{m}^{2}$ and $200 \mathrm{~m}^{2}$ resulted in a mean annual mains water savings of $25 \mathrm{~kL}-56 \mathrm{~kL}(16 \%-11 \%), 32 \mathrm{~kL}-87 \mathrm{~kL}(20 \%-17 \%)$ and 37 kL-114 kL (23\%-22\%), respectively. Case studies in Newcastle, Australia by Coombes et al. [41, 42] evaluated RWH systems for their potential water savings. They collected surface run-off data from 27 residential sites in four separate underground rainwater tanks with sizes ranging from $9 \mathrm{~kL}$ to $15 \mathrm{~kL}$. By using water for hot water system and toilet flushing, they estimated an internal water saving of approximately $45 \%$. Similarly, Coombes et al. [42] analyzed the performance of a RWH system with a roof catchment area of $115 \mathrm{~m}^{2}$ and found that over a period of one year (November 2000 to November 2001), a total of 27,800 L of rainwater was used from the tank, resulting in a $52 \%$ reduction in mains water use. The requirement for different tank sizes across a city was also identified by Khastagir and Jayasuriya [43], who calculated the required rainwater tank sizes for achieving a $90 \%$ reliability in water supply in Melbourne, Australia. They used RWH systems to supply water for toilets and gardens based on different roof catchment sizes ranging from 100 to $200 \mathrm{~m}^{2}$ and concluded that there is a considerable difference in required tank size (1.1-2.5 $\mathrm{kL}$ for a $200 \mathrm{~m}^{2}$ catchment) due to the spatial variability of rainfall across the Greater Melbourne region. These results were supported by Imteaz et al. [44] who compared the reliability of a RWH system in
Melbourne and found that due to high variability in rainfall for both the dry and average years, the calculated reliabilities were very similar for Central Melbourne, with 60\% demand being met and for South-East Melbourne, with $80 \%$ demand being met. Similarly, Ghisi et al. [45]tested the potential water savings in the residential sector of south-eastern Brazil with the use of a RWH system. Using data from 195 cities across the region and water demands of 90-300 L/d, they concluded that the potential for potable water savings varied from 12 to $79 \%$. They also noted that cities with higher potable water demand needed rainwater tanks with a lower volume due to the lower dependence on non-potable water. The volume of rainfall does not necessarily reduce the potable water savings in that case. Ghisi and Souza [46]calculated the potential for potable water savings using a RWH system across thirteen cities in the world with different climates. Using roof catchment areas of 100, 200 and $400 \mathrm{~m}^{2}$ and water demands of 50,100, 150 and $200 \mathrm{~L} / \mathrm{p} / \mathrm{d}$, they concluded that cities with higher annual rainfall but with distinct wet and dry periods do not achieve the same potable water saving as those with consistent rainfall and therefore they need larger tanks to account for a higher variability in rainfall. This conclusion is similar to Coombes and Kozarovski[33]who analyzed the performance of rainwater tanks across different climate zones in NSW and stated that significant potable water savings is possible even in low rainfall areas and that these savings increase with water demand. However, Coombes and Kozarovski [33]suggested that an increased water demand rather than an increased tank size has the potential to enhance potable water savings. Although there have been many researches on water savings aspects of RWH systems at individual locationsthere is a lack on regionalization studies to seek optimization of tank size to reflect the effects of local conditions, e.g., rainfall, loss and demand characteristics over a large region. To overcome this research gap, an approach is proposed here, which selects a large number of locations in a region to generalize the RWH system design. Regionalization data for eastern Australia has been adopted in this researchand considered as the samples to other areas of hydrology such as in flood data analysis (e.g.,Haddad and Rahman, [47];Zaman et al.,[48], rainfall analysis HaddadJohnson et al., [49] and rainfall runoff modelling e.g. Caballero and Rahman, [50]. The adopted regionalization data in this study enables characterization of regional behavior of rainfall water savings and reliability of a RWH system over a large region, andthe proposed approach delivers easy for use of design curves to determine adequate rainwater tank size at any random location within the study region based on reliability, desired water savings and local rainfall of western regions of Rwanda.

\section{Methodology and data}

We have implemented a behavioral model (yield-before-spillage (YBS) type) to simulate long term performance of a RWH system (1 kL-20 kL tank size) across the western region of Rwanda. According to the studies ofHajani and Rahman [36],we have attempted to generalize the performance of a RWH system across the western region by using rainfall data from 10 different rainfall stations. This failed to capture effectively the spatial variability in the 
rainfall and performance of RWH system across the region, which is characterized by a high degree of spatial rainfall variability. To overcome this limitation, we used daily rainfall data fromdifferent locations across the region. Furthermore, we express the research findings via a simplified color-coded graph, which efficiently depicts the general relationship among mean annual rainfall (MAR), reliability, water savings and tank size for a given type of water use across the region.Our adopted definition of reliability (eq (1)) is similar to that of Basinger et al. [51] and is the ratio of days where the RWH system can supply the intended demand without mains top-up $\left(\mathrm{N}_{\mathrm{dm}}\right)$ against the total number of days simulated in the modeling exercise $\left(\mathrm{N}_{\text {sim }}\right)$. The water savings is the total amount of harvested water used in a year on average (the yearly average is calculated as the sum of water savings over all the simulated years divided by the number of simulated years $\left(\mathrm{N}_{\text {sim }}\right)$.

$$
\text { Reliability }=\frac{\mathbb{N}_{d m}}{\mathbb{N}_{\text {sim }}}
$$

The model accounts for a number of variables including tank size, daily rainfall, losses (accounts for factors such as gutter overflow and depression losses), daily water demand, mains top-up and tank spillage. The model uses water balance equations to calculate the reliabilities and water savings as defined below:

$$
\begin{aligned}
& \mathrm{R}_{\mathrm{t}}=\mathrm{D}_{\mathrm{t}} \text {; when } \mathrm{I}_{\mathrm{t}}+\mathrm{S}_{\mathrm{t}-1} \geq \mathrm{D}_{\mathrm{t}} \\
& \mathrm{R}_{\mathrm{t}}=\mathrm{I}_{\mathrm{t}}+\mathrm{S}_{\mathrm{t}-1} \text {; when } \mathrm{I}_{\mathrm{t}}+\mathrm{S}_{\mathrm{t}-1}<\mathrm{D}_{\mathrm{t}}
\end{aligned}
$$

Where $D_{t}$ is the daily water demand in $\mathrm{m}^{3}$ for each day; $S_{t-1}$ is the final storage in the tank $\left(\mathrm{m}^{3}\right)$ for the previous day; $\mathrm{R}_{\mathrm{t}}$ is the release from the rainwater tank for each day $\left(\mathrm{m}^{3}\right)$ and $\mathrm{I}_{\mathrm{t}}$ is the inflows into the rainwater tank from the roof catchment each day $\left(\mathrm{m}^{3}\right)$. The spill from the rainwater tank $\left(\mathrm{SP}_{\mathrm{t}}\right)$ is also necessary to calculate the current day storage in the rainwater tank based on equations (4) and (5)

$$
\begin{aligned}
& \mathrm{SP}_{\mathrm{t}}=\mathrm{I}_{\mathrm{t}}+\mathrm{S}_{\mathrm{t}-1}-\mathrm{D}_{\mathrm{t}}-\mathrm{S}_{\mathrm{MAX}} ; \\
& \text { when } \mathrm{I}_{\mathrm{t}}+\mathrm{S}_{(\mathrm{t}-1)}-\mathrm{D}_{\mathrm{t}}>\mathrm{S}_{\mathrm{MAX}}(4) \\
& \mathrm{SP}_{\mathrm{t}}=0 \text {; when } \mathrm{I}_{\mathrm{t}}+\mathrm{S}_{(\mathrm{t}-1)}-\mathrm{D}_{\mathrm{t}} \leq \mathrm{S}_{\mathrm{MAX}}
\end{aligned}
$$

where $S_{M A X}$ is the design storage capacity of the tank $\left(\mathrm{m}^{3}\right)$. The final storage for each day $\left(\mathrm{S}_{\mathrm{t}}\right)$ is calculated using equations (6) and (7),

$$
\begin{aligned}
& \mathrm{S}_{\mathrm{t}}=\mathrm{S}_{\mathrm{MAX}} \text {; if } \mathrm{SP}_{\mathrm{t}}>0 \\
& \mathrm{~S}_{\mathrm{t}}=\mathrm{S}_{(\mathrm{t}-1)}+\mathrm{I}_{\mathrm{t}}-\mathrm{R}_{\mathrm{t}} \text {; if } \mathrm{SP}_{\mathrm{t}}=0
\end{aligned}
$$

There are few limitations with the adopted model as it uses a daily time step. Coombes et al. [52]indicated that for RHW system modelling the preferred method is continuous simulation at a sub-daily time step such as PURRS developed by Coombes[53]. Hardy et al. [54]supported this and suggested that a continuous simulation at a sub-daily time step would give more accurate results of volume sensitive systems. Furthermore, Coombes and Barry [55]established that a daily time step using average water demands underestimated the mains water savings compared to sub daily time step and climate dependents water demand. However, there is only limited water demand data at sub-daily time steps, and hence it is not feasible to adopt sub-daily time step in many applications. The second limitation of the adopted model is its simplistic nature of indoor and outdoor water demand calculation. The model uses an indoor blanket water demand and disregards several influential factors including household income, temperature, rainfall depth and frequency. These factors have been reported to be important in water demand modelling by Coombes and Barry [56] andCoombes et al. [57]. The impacts of these factors on water savings and reliability have not been incorporated in this study, which will be undertaken in a future study. Our model uses an irrigation demand of a maximum of $10 \mathrm{~mm}$ per $\mathrm{m}^{2}$ of lawn area per day. In the adopted model, if the daily rainfall exceeded $10 \mathrm{~mm}$, irrigation demand was kept zero on that day, and after a heavy rainfall event (daily rainfall exceeding $50 \mathrm{~mm}$ ), irrigation demand was kept zero for a number of subsequent days (one day for each $25 \mathrm{~mm}$ of rainfall). However, it is assumed that use of daily time step would not undermine the accuracy of the results as far as practical application is concerned. The outputs from the model were imported into R-Studio where the design curves were created comparing the reliabilities and water savings of different locations in western region of Rwanda for different tank sizes.We use daily rainfall data from rainlocations across the western region.The daily rainfall data for these locations have been obtained from the Rwandan Meteorological Agency. For this study, the mean annual rainfall (MAR) across the selected locations ranged from 600 to $1400 \mathrm{~mm}$ with an average of $959 \mathrm{~mm}$. This shows a high degree of spatial variability in MAR across the region.There are several combinations of water use adopted for the calculation of the daily demand, including toilet and laundry use, irrigation, and a combination of the former two The performance of different sized rainwater tanks was examined to enable selection of an optimum rainwater tank size for a given application. Variations in input data were considered to provide a greater range of performances for the RWH system such as different site areas, and numbers of users/house occupants. The numbers of occupants used for the assessment vary from 4 to 6 people. Total site areas of 350 $\mathrm{m}^{2}, 450 \mathrm{~m}^{2}$ and $550 \mathrm{~m}^{2}$ with catchment (roof), lawn and impervious areas for each size are considered, as can be seen in Table 2. The adopted roof areas are similar to the areas used by BMT WBM Pty Ltd and Aither Pty Ltd [32] who used roof areas of $180 \mathrm{~m}^{2}, 228 \mathrm{~m}^{2}$ and $276 \mathrm{~m}^{2}$ for their analysis of RWH systems in Western Sydney. The water demand values for the different uses depend on several factors; For this study, the adopted demand data are slightly different than those of Hajani and Rahman [36]. Toilet and laundry use took into account the volume of water used in each toilet flush and washing cycle as well as the amount of usage each day. For this study the volume of the toilet was set at a 3-star water efficiency and labelling standards (WELS) rating of $6 \mathrm{~L}$ per flush. It was assumed that each person uses a toilet 6 times in a day, an equivalent water use of $36 \mathrm{~L} / \mathrm{p} / \mathrm{d}$, which is $5 \mathrm{~L} / \mathrm{p} / \mathrm{d}$ smaller than the adopted value of $41 \mathrm{~L} / \mathrm{p} / \mathrm{d}$. It is also assumed that a washing machine with a volume of $80 \mathrm{~L}$ per wash is used at a frequency of once per day.In the modelling, the runoff loss is modelled by a run-off coefficient (to account for losses for the factors such as gutter overflow and a loss due to first flush). A run-off coefficient is set at 0.85 , which is within the range found by van der Sterren et al. [58], and within the typical estimates of 0.8 and 0.95 for roof catchments[39, 43, 
59-61].The first flush volume is based on Hajani and Rahman [36], which is set at $50 \mathrm{~L}$. However, this is consistent only for

Table. 2 Different site areas used in modelling RWH system

\begin{tabular}{llll} 
Total Site Area $\left(\mathrm{m}^{2}\right)$ & Roof Area $\left(\mathrm{m}^{2}\right)$ & Lawn Area $\left(\mathrm{m}^{2}\right)$ & Impervious Area $\left(\mathrm{m}^{2}\right)$ \\
\hline 350 & 150 & 150 & 50 \\
450 & 200 & 200 & 50 \\
550 & 250 & 250 & 50
\end{tabular}

\section{RESULTS}

The reliability and water savings were calculated with the total period of rainfall data available for each of the selectedsites across western region of Rwanda using areas of $250 \mathrm{~m}^{2}, 250 \mathrm{~m}^{2}$ and $50 \mathrm{~m}^{2}$ for roof, lawn and impervious parts, respectively. The reliability and water savings for different rainwater tank sizes and water usage can be seen in Figs. 1-3, with each scale colored with the corresponding MAR. As an example, for Fig. 1(a), one needs to find the MAR at the desired location, and select the color corresponding to the MAR value from the vertical axis (on the right side of the graph) and then for a given tank size (from the horizontal axis), the reliability can be found from the vertical axis (left side). Fig. 1(a) displays the reliability for toilet and laundry usage for different rainwater tank sizes for different rainfall locations, whilst also comparing with the MAR. From this figure it is seen that for a 5-kL tank, the reliabilities vary with the MAR from $49 \%$ to $93 \%$ with an average of $80 \%$. Fig. 1(a) also shows that the reliability increases with the MAR, though there are some larger reliability values for lower MAR for the larger rainwater tank sizes, which is likely due to greater spatial variability in rainfall across the region. For example, an area with more uniformly distributed daily rainfall is likely to provide higher reliability compared with an area having less uniformly distributed rainfall even though both the areas have the same MAR values. Fig. 1(b) displays the water savings per year for the reliability found in Fig. 1(a) and it can be seen that for a $5-\mathrm{kL}$ rainwater tank, the annual water savings range from $35 \mathrm{~kL} / \mathrm{yr}$, to $66 \mathrm{~kL} / \mathrm{yr}$, depending on the reliability. It is seen that the higher reliability correlates well with increased water savings as expected. The water savings corresponding to the average reliability of a $5-\mathrm{kL}$ a roof area of $250 \mathrm{~m}^{2}$ that requires $20 \mathrm{~L}$ of the first flush per $100 \mathrm{~m}^{2}$ of roof area.

rainwater tank is $57 \mathrm{~kL} / \mathrm{yr}$. The reliability and water savings for irrigation use across the region is seen in Fig. 2(a) and (b).The reliability for irrigation use is lower than that of the toilet and laundry use, and also results in a greater range of reliabilities. It is seen in Fig. 2(a) that the reliability for a $5 \mathrm{~kL}$ rainwater tank ranges from $35 \%$ to $77 \%$ with an average of $58 \%$ for irrigation use. The water savings for irrigation use across the region is seen in Fig. 2(b). For a 5-kL rainwater tank, the annual water savings range from $27 \mathrm{~kL}$ to $73 \mathrm{~kL}$ (52 $\mathrm{kL}$ for the average reliability). Fig. 3(a) and (b) displays the water savings for a RWH system for combined use i.e., toilet, laundry and irrigation. The reliability varies greatly across the region as seen in Fig. 3(a). A 5-kL rainwater tank can meet the combined demand with a reliability varying from $31 \%$ to $70 \%$, with an average of $52 \%$. It is seen in this figure that the reliability does not exceed $90 \%$ for any tank size at any location across the region, which means that there is no enough rainwater to meet demand at $100 \%$ of the days unless special demand management is made, such as the self-imposed water restrictions as explained byvan der Sterren et al. [58]. The reliability for combined use is lower than that of the other two uses, though the potential for water savings increases with the combined use as shown in Fig. 3(b). The water savings for a $5 \mathrm{~kL}$ rainwater tank ranges from 45 $\mathrm{kL}$ to $95 \mathrm{~kL}$ ( $73 \mathrm{~kL}$ for the average reliability). As can be seen in Figs. 1-3, there is a large variation in reliabilities and water savings for the different locations in the region. This suggests that a single rainwater tank size is not appropriate for the region. The correlation between the reliability and MAR was examined for a 5-kL rainwater tank. The results show that the reliability is moderately correlated with the MAR, as represented by equations 8-10.

$$
\begin{gathered}
\mathrm{R}_{\mathrm{TL}}=0.0436 \times(\text { MAR })+37.775, \mathrm{R}^{2}=0.57 \\
\mathrm{R}_{\mathrm{I}}=0.0452 \times(\text { MAR })+15.103, \mathrm{R}^{2}=0.63 \\
\mathrm{R}_{\mathrm{C}}=0.0426 \times(\text { MAR })+11.017, \mathrm{R}^{2}=0.68 \\
\text { Reliability vs. Tank Size }
\end{gathered}
$$

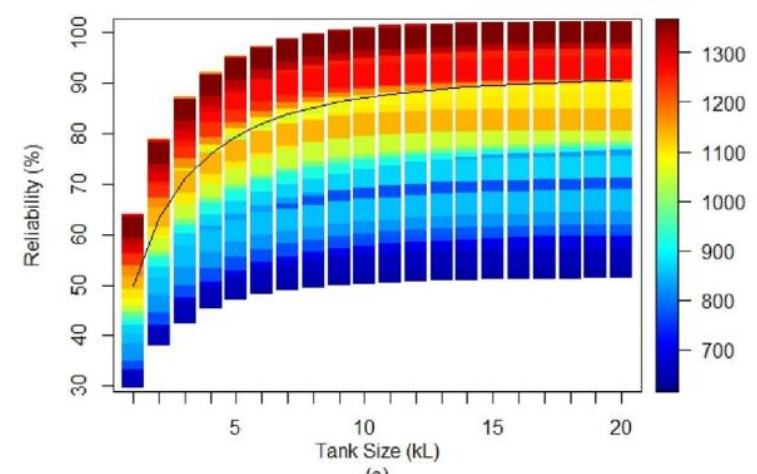

(a)

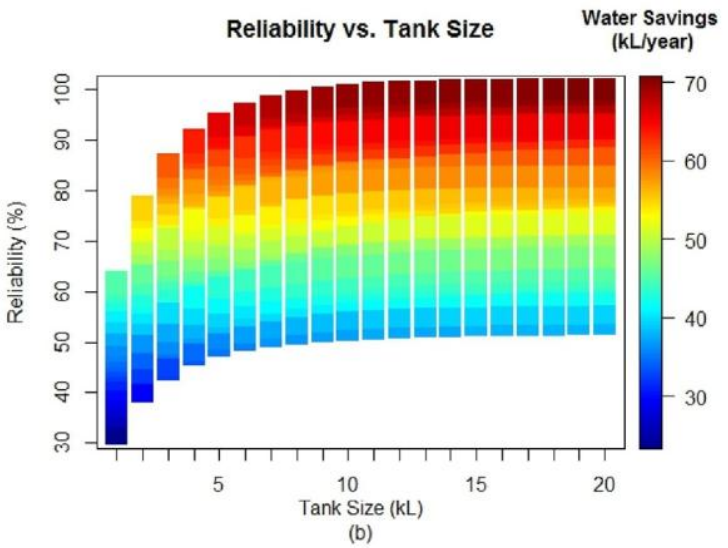




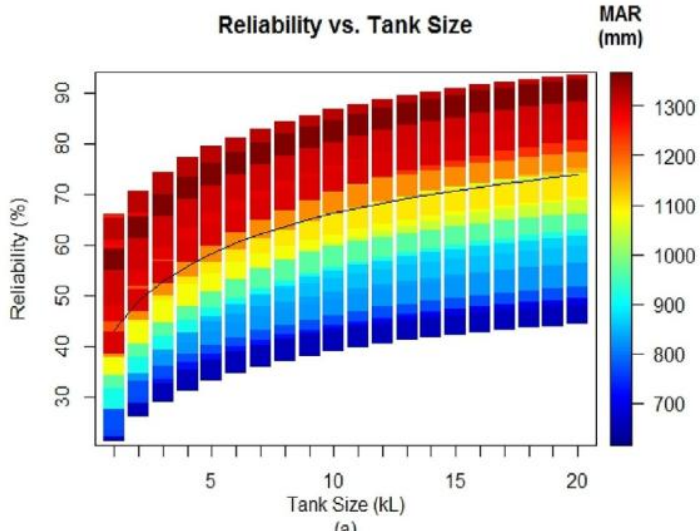

(a)

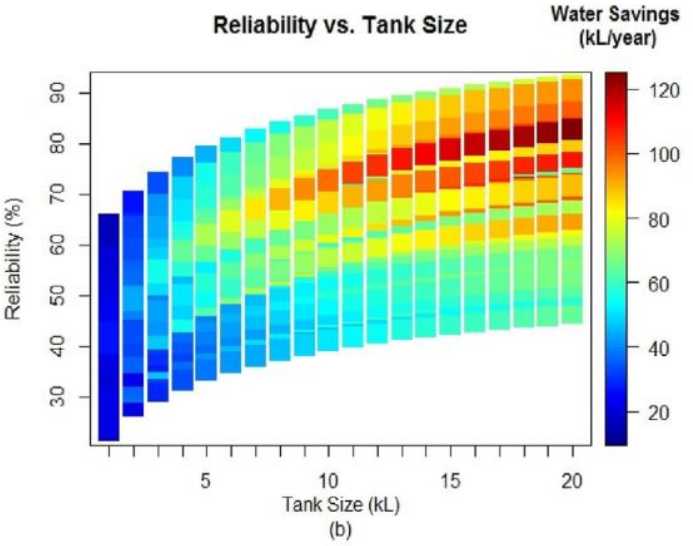

(b)

Fig. 1 (a) Reliability

for a RWH system for different MAR across western region for toilet and laundry use (black curve represents average reliability across all the locations) (b) Water savings for a RWH system for different reliabilities for toilet and laundry use.

Fig. 2 (a) Reliability for a RWH system for different MAR across the region for irrigation use (black curve represents average reliability across all the locations), (b) Water Savings for a RWH system for different reliabilities for irrigation use.

MAR. All the tank sizes considered in this study except for 1

Where $\mathrm{R}_{\mathrm{TL}}, \mathrm{R}_{\mathrm{I}}$ and $\mathrm{R}_{\mathrm{C}}$ are the reliabilities (\%) for toilet and laundry use, irrigation use and combined use, respectively and MAR is the mean annual rainfall $(\mathrm{mm})$. Fig. 4 presents the regression relationship between reliability and MAR (for a $5-\mathrm{kL}$ tank) as represented by equations (7)-(9), which shows that reliability of a RWH system generally increases with the

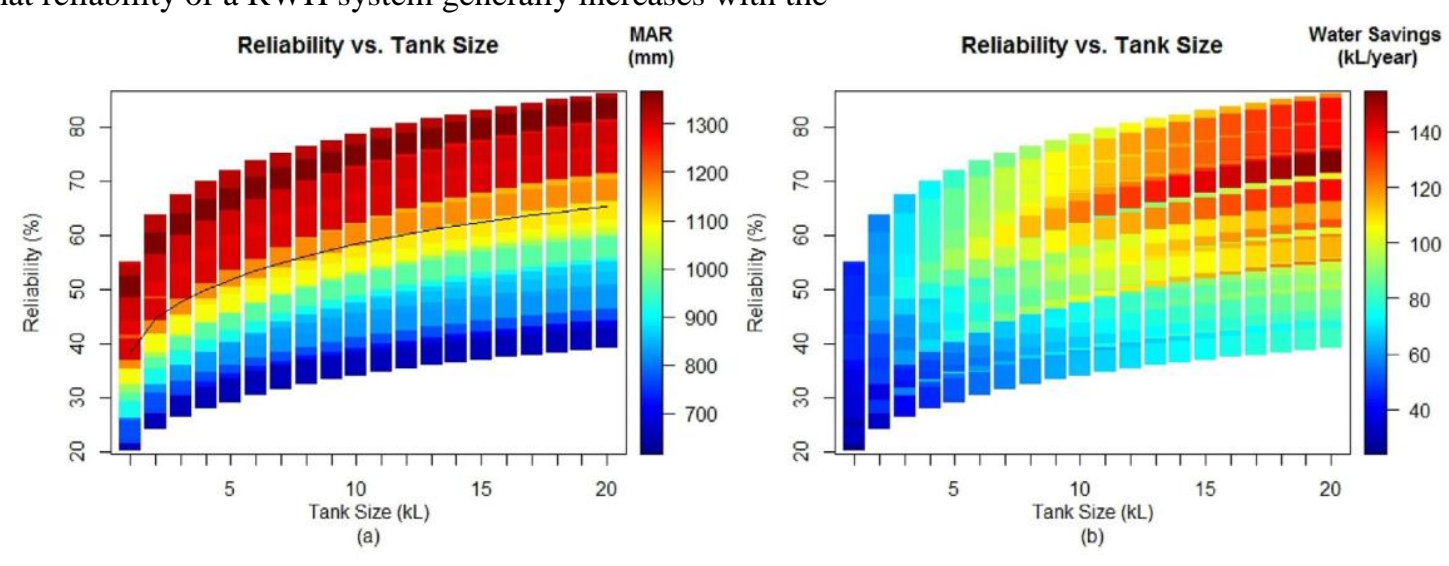

Fig. 3. (a) Reliability for a RWH system for different MAR across the region for combined use (toilet, laundry and irrigation) (black curve represents average reliability across all the locations), (b) Water Savings for a RWH system for different reliabilities for combined use (toilet, laundry and irrigation). ability to deduct $40 \%$ of potable water demand. It is noted that for $1 \mathrm{~kL}$ tank size, can be metonly by selecting a native garden for a $600 \mathrm{~m}^{2}$ share size, with $250 \mathrm{~m}^{2}$ roof and $250 \mathrm{~m}^{2}$ garden areas. 

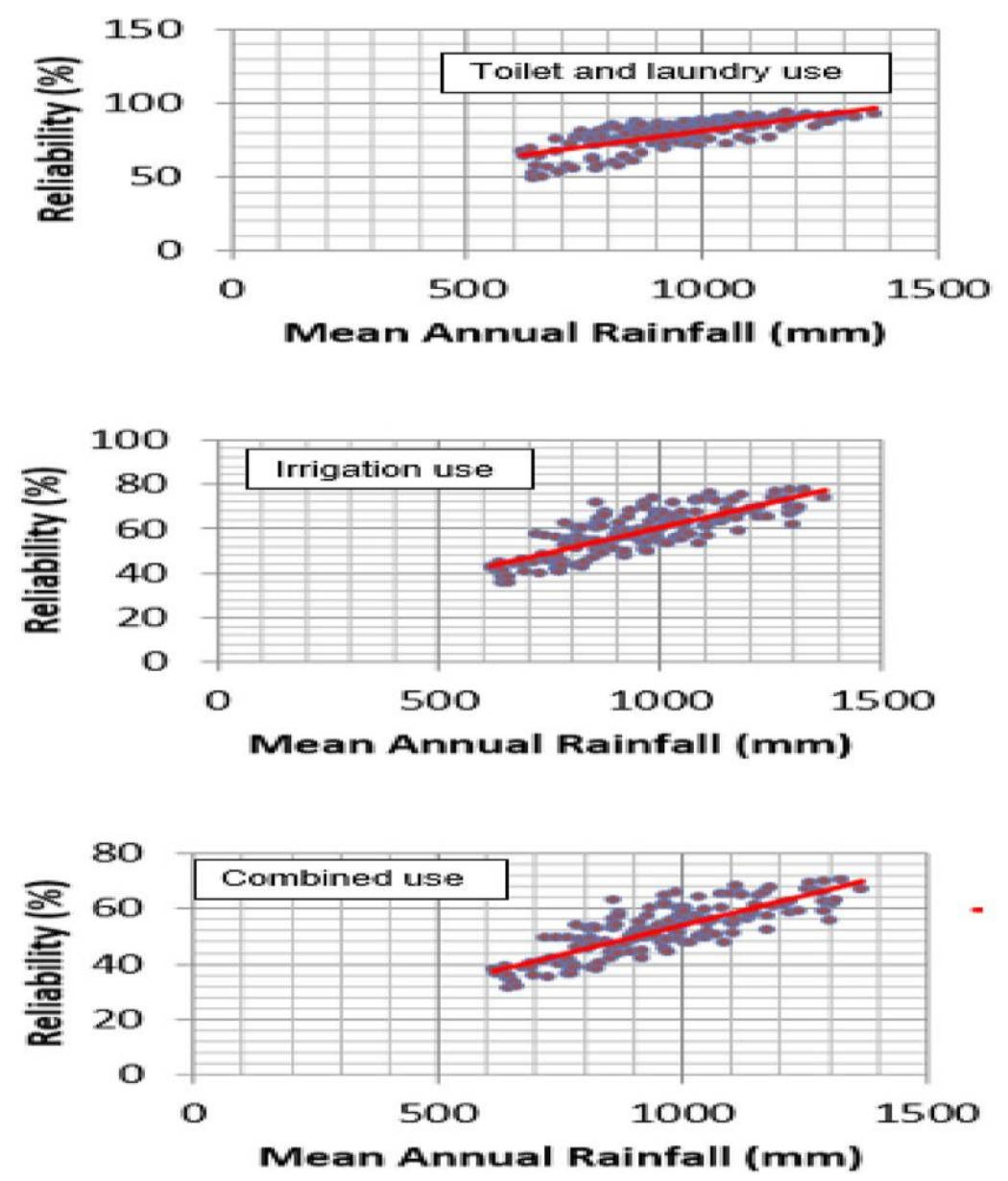

Figure 4: Plots showing correlation between reliability and MAR

\section{DISCUSSION}

The developed design curves, presented in Figs. 1-4 for three different types of water usages, can be used easily to select an optimum rainwater tank size at any arbitrary location within the westernregion of Rwanda by following the below steps:

- Select the desired use of rainwater and the corresponding design curve. For toilet and laundry use select Fig. 1for irrigation useselect Fig. 2and for toilet, laundry and irrigation use select Fig. 3

- Select a candidate tank size in the range of $1 \mathrm{~kL}-20$ $\mathrm{kL}$.

- Based on the MAR color indicator and candidate tank size, read the reliability of the candidate tank size from Fig. 1(a) orFig.2a or Fig.3a by drawing a horizontal line through the MAR color indicator.

- For the obtained reliability and tank size, estimate the mean annual water savings in $\mathrm{kL} /$ year.

- Select the smallest tank size among all the candidate tank sizes that achieves the desired reliability and water savings. It should be noted that water savings should be the main target than the reliability where mains water supply is available however, for pre-urban areas, where mains water is unavailable, reliability should be the main target to ensure continuity of water supply.
The results presented in Figs. 1-3generally agrees with Rahman et al. [35]who found a slightly greater reliability value using a smaller roof area for combined use. The water savings from a 5-kL tank from this study are compared with three similar studies in Table 3.It can be seen that the water savings for a 5-kL tank found here for combined use (45-95 $\mathrm{kL})$ lie within the results reported by Coombes and Kuczera [40](37-114 kL). The water savings in this study for combined use (average $73 \mathrm{~kL}$ ) are larger (by about 20\%) than those reported by Hajani and Rahman [36](average $61 \mathrm{~kL}$ ). For a 5-kL tank and combined use, Rahman et al. [35]found an average water savings of $59 \mathrm{~kL}$, which is $73 \mathrm{~kL}$ in this study (about 24\% higher). These results show some differences in water savings by different studies. Since water savings and reliability of a rainwater tank depend largely on MAR at the site of interest, the differences noted in Table 3are expected as MAR varies widely from site to site and the reported studies adopted different sets of sites to calculate water savings and reliability. However, the above three studies (Hajani and Rahman, [36]; Rahman et al., [35]; Coombes and Kuczera,[40]focused on rainwater harvesting in Sydney by selecting only a handful of rainfall stations e.g. 10 stations by Rahman et al., [35]. Since the Greater Sydney region has an area of about $12,000 \mathrm{~km}^{2}$ and ischaracterized by a high rainfall gradient. 


\section{Deterministic For Rain Water Harvesting Storage Capabilities with the Design Curve Technique, A Strategy for Attaining Copiousness of Water}

Table 3Comparison of water savings (in $\mathrm{kL}$ ) in Sydney region for a 5-kL tank [minimum-maximum (average)]

\begin{tabular}{|c|c|c|c|c|}
\hline Water use & $\begin{array}{l}\text { This } \\
\text { study }\end{array}$ & $\begin{array}{l}\text { Rahman et al. } \\
\text { (2012) }\end{array}$ & $\begin{array}{l}\text { Hajani and Rahman } \\
2014 a\end{array}$ & $\begin{array}{c}\text { Coombes } \\
\text { Kuczera (2003) }\end{array}$ \\
\hline Toilet and laundry & $35-66(57$ & $33-35(34)$ & $33-34(33)$ & - \\
\hline Irrigation & $27-73(52$ & $43-57(48)$ & $46-54(51)$ & - \\
\hline
\end{tabular}

Combined (i.e., toilet $\quad 45-95(73 \quad 54-69(59) \quad 56-62(61)$

$37-114(-)$

+ laundry + irrigation) $\quad$ )

our study selected many locations to adequately capture the spatial variability of rainfall across the western region of Rwanda. Furthermore, our study presents the research findings via simplified color-coded design curves, which efficiently depicts the general relationship among MAR, reliability, water savings and tank size for three different water usages covering the entire region. In this study, it is found that a single rainwater tank size such as $3 \mathrm{~kL}$ cannot achieve optimum water savings in areas of low MAR in the region in many pre-urban sites of country, reliability is quite important as there is no mains water supply and hence a larger tank size is desirable to ensure the continuity of water supply. For municipal where mains water is available, water savings aspect is more important than the reliability to minimize pressure on water supply system. To achieve a greater water savings across the country, the existing water policy permits revision is needed where custom design of a RWH system should be targetedwhere given household should be mandated based on the local rainfall and water demand characteristics. This will allow relaxation of water restrictions frequently imposed by water supply authority in Rwanda. The results of this study would be useful for RWH system implementation in the whole country if used.

\section{CONCLUSION}

This study investigated the performance of rainwater harvesting (RWH) systems for different locations across western region in Rwanda with the aim of developing design curves to find adequate tank size based on reliability, water savings and local rainfall. Using the daily rainfall data at the selected locations, it has been found that there is a great variation in mean annual rainfall across the selected locations and that no common tank size can be selected for the region. It has been found that there is a moderate correlation between the tank reliability and mean annual rainfall. The findings of this study would provide guidance in selecting an adequate tank size given the mean annual rainfall and water demand at any arbitrary location within the region. Furthermore, the developed methodology can be adapted to other geographic locations to find an adequate rainwater tank size.

\section{REFERENCES}

[1] W. H. Organization and UNICEF., Progress on sanitation and drinking-water. World Health Organization, 2013.

[2] G. J. W. H. O. WHO, "Guidelines for drinking-water quality," vol. 216, pp. 303-304, 2011
[3] C. de Pizay and F. Villié-Morgon, "WHO/UNICEF Joint Monitoring Programme for Water Supply and Sanitation (JMP)," 2010.

[4] R. Bain, R. Cronk, J. Wright, H. Yang, T. Slaymaker, and J. J. P. M Bartram, "Fecal contamination of drinking-water in low-and middle-income countries: a systematic review and meta-analysis," vol 11, no. 5, p. e1001644, 2014.

[5] R. Bain et al., "Global assessment of exposure to faecal contamination through drinking water based on a systematic review," vol. 19 , no. 8 , pp. 917-927, 2014

[6] J. Wolf, S. Bonjour, A. J. J. o. W. Prüss-Ustün, and Health, "An exploration of multilevel modeling for estimating access to drinking-water and sanitation," vol. 11, no. 1, pp. 64-77, 2013

[7] K. Onda, J. LoBuglio, J. J. I. j. o. e. r. Bartram, and p. health, "Global access to safe water: accounting for water quality and the resulting impact on MDG progress," vol. 9, no. 3, pp. 880-894, 2012.

[8] D. J. F. R. Water, "National Primary Drinking Water Regulations, Total Coliforms (Including Fecal Coliforms and E. Coli) Final Rule," vol. 54 p. $27544,1989$.

[9] S. Edberg, E. Rice, R. Karlin, and M. J. J. o. a. m. Allen, "Escherichia coli: the best biological drinking water indicator for public health protection," vol. 88, no. S1, pp. 106S-116S, 2000.

[10] J. A. Wright, H. Yang, K. J. P. Walker, Space, and Place, "Do international surveys and censuses exhibit 'Dry Season'bias?," vol. 18, no. 1, pp. 116-126, 2012

[11] Y. Ouyang, P. Nkedi-Kizza, Q. Wu, D. Shinde, and C. J. W. r. Huang, "Assessment of seasonal variations in surface water quality," vol. 40, no. 20, pp. 3800-3810, 2006.

[12] R. J. E. Wright and Infection, "The seasonality of bacterial quality of water in a tropical developing country (Sierra Leone)," vol. 96, no. 1, pp. 75-82, 1986.

[13] A. F. J. de Moraes and C. J. J. o. c. p. Rocha, "Gendered waters: the participation of women in the 'One Million Cisterns' rainwater harvesting program in the Brazilian Semi-Arid region," vol. 60, pp. 163-169, 2013

[14] C. Christian Amos, A. Rahman, and J. J. W. Mwangi Gathenya, "Economic analysis and feasibility of rainwater harvesting systems in urban and peri-urban environments: A review of the global situation with a special focus on Australia and Kenya," vol. 8, no. 4, p. 149, 2016.

[15] A. Campisano et al., "Urban rainwater harvesting systems: Research, implementation and future perspectives," vol. 115, pp. 195-209, 2017.

[16] C. C. Amos, A. Rahman, and J. M. J. J. o. c. p. Gathenya, "Economic analysis of rainwater harvesting systems comparing developing and 
developed countries: A case study of Australia and Kenya," vol. 172, pp. 196-207, 2018.

[17] A. Palla, I. Gnecco, and P. J. J. o. e. m. La Barbera, "The impact of domestic rainwater harvesting systems in storm water runoff mitigation at the urban block scale," vol. 191, pp. 297-305, 2017.

[18] X. Jing, S. Zhang, J. Zhang, Y. Wang, Y. J. R. Wang, Conservation, and Recycling, "Assessing efficiency and economic viability of rainwater harvesting systems for meeting non-potable water demands in four climatic zones of China," vol. 126, pp. 74-85, 2017.

[19] L. Domènech and D. J. J. o. C. p. Saurí, "A comparative appraisal of the use of rainwater harvesting in single and multi-family buildings of the Metropolitan Area of Barcelona (Spain): social experience, drinking water savings and economic costs," vol. 19, no. 6-7, pp. 598-608, 2011.

[20] T. Morales-Pinzón, J. Rieradevall, C. M. Gasol, and X. J. J. o. C. P. Gabarrell, "Modelling for economic cost and environmental analysis of rainwater harvesting systems," vol. 87, pp. 613-626, 2015.

[21] S. R. Ghimire, J. M. Johnston, W. W. Ingwersen, and S. J. J. o. c. p. Sojka, "Life cycle assessment of a commercial rainwater harvesting system compared with a municipal water supply system," vol. 151, pp. 74-86, 2017.

[22] P. J. A. J. o. W. R. Coombes, "Energy and economic impacts of rainwater tanks on the operation of regional water systems," vol. 11, no. 2, pp. 177-191, 2007.

[23] S. E. J. G. Nicholson and p. change, "The nature of rainfall variability over Africa on time scales of decades to millenia," vol. 26, no. 1-3, pp. 137-158, 2000.

[24] A. J. G. C. Siebert, "Hydroclimate extremes in Africa: variability, observations and modeled projections," vol. 8, no. 6, pp. 351-367, 2014.

[25] I. Muhire, F. Ahmed, K. J. T. Abutaleb, and A. Climatology, "Relationships between Rwandan seasonal rainfall anomalies and ENSO events," vol. 122, no. 1, pp. 271-284, 2015.

[26] L. Ilunga and I. J. G.-E.-T. Muhire, "Comparison of the Rwandan annual mean rainfall fluctuations with El-Nino/La Nina events and sunspots," vol. 34, no. 1-2, pp. 75-86, 2010.

[27] W. Mbungu, V. Ntegeka, F. Kahimba, M. Taye, P. J. P. Willems, and P. A. B. C. Chemistry of the Earth, "Temporal and spatial variations in hydro-climatic extremes in the Lake Victoria basin," vol. 50, pp. 24-33, 2012.

[28] I. Muhire and F. J. S. A. G. J. Ahmed, "Spatio-temporal trend analysis of precipitation data over Rwanda," vol. 97, no. 1, pp. 50-68, 2015.

[29] C. F. Ropelewski and M. S. J. M. w. r. Halpert, "Global and regional scale precipitation patterns associated with the El Niño/Southern Oscillation," vol. 115, no. 8, pp. 1606-1626, 1987.

[30] N. Saji and T. J. C. R. Yamagata, "Possible impacts of Indian Ocean dipole mode events on global climate," vol. 25, no. 2, pp. 151-169, 2003.

[31] C. WenhajiNdomeni, E. Cattani, A. Merino, and V. J. Q. J. o. t. R. M. S. Levizzani, "An observational study of the variability of East African rainfall with respect to sea surface temperature and soil moisture," vol. 144, pp. 384-404, 2018.
[32] C. Snook, A. Rahman, M. van der Sterren, M. M. Haque, and E. J. t. I. W. S. U. D. Hajani, "Developing design curves for rainwater harvesting in Greater Sydney," p. 495, 2015.

[33] P. J. Coombes and P. Kozarovski, "Development of a regional model to understand the hydrological and economic benefits of rainwater tanks across New South Wales," in 29th Hydrology and Water Resources Symposium: Water Capital, 20-23 February 2005, Rydges Lakeside, Canberra, 2005, p. 658: Engineers Australia.

[34] M. T. Pawlak, M. Bui, M. Amir, D. L. Burkhardt, A. K. Chen, and R. P. J. A. o. d. Dellavalle, "Legislation restricting access to indoor tanning throughout the world," vol. 148, no. 9, pp. 1006-1012, 2012.

[35] A. Rahman, J. Keane, M. A. J. R. Imteaz, Conservation, and Recycling, "Rainwater harvesting in Greater Sydney: Water savings, reliability and economic benefits," vol. 61, pp. 16-21, 2012.

[36] E. Hajani and A. J. W. Rahman, "Reliability and cost analysis of a rainwater harvesting system in peri-urban regions of Greater Sydney, Australia," vol. 6, no. 4, pp. 945-960, 2014.

[37] E. J. B. Ghisi and Environment, "Potential for potable water savings by using rainwater in the residential sector of Brazil," vol. 41, no. 11, pp. 1544-1550, 2006.

[38] F. A. Abdulla and A. W. J. D. Al-Shareef, "Roof rainwater harvesting systems for household water supply in Jordan," vol. 243, no. 1-3, pp. 195-207, 2009.

[39] T. Herrmann and U. J. U. w. Schmida, "Rainwater utilisation in Germany: efficiency, dimensioning, hydraulic and environmental aspects," vol. 1, no. 4, pp. 307-316, 2000.

[40] P. J. Coombes and G. Kuczera, "Analysis of the performance of rainwater tanks in Australian capital cities," in 28th International Hydrology and Water Resources Symposium: About Water; Symposium Proceedings, 2003, p. 2: Institution of Engineers, Australia.

[41] P. J. Coombes, J. R. Argue, and G. J. U. W. Kuczera, "Figtree Place: a case study in water sensitive urban development (WSUD)," vol. 1, no. 4, pp. 335-343, 2000.

[42] P. J. Coombes, G. Kuczera, and J. D. J. A. J. o. W. R. Kalma, "Economic, water quantity and quality impacts from the use of a rainwater tank in the inner city," vol. 7, no. 2, pp. 111-120, 2003.

[43] A. Khastagir and N. J. J. o. H. Jayasuriya, "Optimal sizing of rain water tanks for domestic water conservation," vol. 381, no. 3-4, pp. 181-188, 2010.

[44] M. A. Imteaz, A. Rahman, A. J. R. Ahsan, Conservation, and Recycling, "Reliability analysis of rainwater tanks: a comparison between South-East and Central Melbourne," vol. 66, pp. 1-7, 2012.

[45] E. Ghisi, D. L. Bressan, M. J. B. Martini, and Environment, "Rainwater tank capacity and potential for potable water savings by using rainwater in the residential sector of southeastern Brazil," vol. 42, no. 4, pp. 1654-1666, 2007.

[46] E. L. Souza and E. J. W. Ghisi, "Potable water savings by using rainwater for non-potable uses in houses," vol. 4, no. 3, pp. 607-628, 2012.

[47] K. Haddad and A. J. J. o. H. Rahman, "Regional flood frequency analysis in eastern Australia: Bayesian GLS regression-based methods 
within fixed region and ROI framework-Quantile Regression vs. Parameter Regression Technique," vol. 430, pp. 142-161, 2012.

[48] M. A. Zaman, A. Rahman, and K. J. J. o. H. Haddad, "Regional flood frequency analysis in arid regions: A case study for Australia," vol. 475, pp. 74-83, 2012.

[49] K. Haddad, F. Johnson, A. Rahman, J. Green, and G. J. J. o. H. Kuczera, "Comparing three methods to form regions for design rainfall statistics: two case studies in Australia," vol. 527, pp. 62-76, 2015.

[50] W. L. Caballero and A. J. H. P. Rahman, "Development of regionalized joint probability approach to flood estimation: a case study for Eastern New South Wales, Australia," vol. 28, no. 13, pp. 4001-4010, 2014.

[51] M. Basinger, F. Montalto, and U. J. J. o. H. Lall, "A rainwater harvesting system reliability model based on nonparametric stochastic rainfall generator," vol. 392, no. 3-4, pp. 105-118, 2010.

[52] P. J. Coombes, A. Frost, G. Kuczera, G. O'Loughlin, and S. Lees, "Rainwater tank options for stormwater management in the upper Parramatta River Catchment," in Water Challenge: Balancing the Risks: Hydrology and Water Resources Symposium 2002, 2002, p. 474: Institution of Engineers, Australia.

[53] P. J. U. W. C. S. A. a. h. u. c. Coombes, "Integrated Water Cycle Modeling Using PURRS (Probabilistic Urban Rainwater and wastewater Reuse Simulator)," 2006.

[54] M. Hardy, G. Kuczera, P. Coombes, E. Barbour, K. J. R. Jurd, and U. Design, "An evaluation of the performance of the application of the urbanCycle model to a gauged urban catchment," p. 340, 2007.

[55] P. J. Coombes, M. E. J. W. s. Barry, and technology, "The effect of selection of time steps and average assumptions on the continuous simulation of rainwater harvesting strategies," vol. 55, no. 4, pp. 125-133, 2007.

[56] P. Coombes and M. Barry, "The spatial variation of climate, household water use, and the performance of rainwater tanks across Greater Melbourne," in WSUD09 Conference. Engineers Australia. Perth, 2009.

[57] P. J. Coombes, G. Kuczera, J. D. J. H. I. H. Kalma, and Proceedings, "A probabilistic behavioural model for simulation of exhouse water demand," p. 793, 2000.

[58] M. Van der Sterren, A. Rahman, G. R. J. W. S. Dennis, and Technology, "Implications to stormwater management as a result of lot scale rainwater tank systems: a case study in Western Sydney, Australia," vol. 65, no. 8, pp. 1475-1482, 2012.

[59] I. J. W. S. Brodie and Technology, "Hydrological analysis of single and dual storage systems for stormwater harvesting," vol. 58, no. 5, pp. 1039-1046, 2008.

[60] E. Ghisi, D. da Fonseca Tavares, V. L. J. R. Rocha, Conservation, and Recycling, "Rainwater harvesting in petrol stations in Brasilia: Potential for potable water savings and investment feasibility analysis," vol. 54, no. 2, pp. 79-85, 2009.

[61] L. Gottschalk and R. J. J. o. h. Weingartner, "Distribution of peak flow derived from a distribution of rainfall volume and runoff coefficient, and a unit hydrograph," vol. 208, no. 3-4, pp. 148-162, 1998. 